\title{
The Use of Box Culvert Precast as a Main Bridge Structure in Arterial Highway Road: An Analysis Study
}

\author{
J Propika ${ }^{1}$, L L Lestari ${ }^{1}$ and J F G Muti ${ }^{1}$ \\ ${ }^{1}$ Department of Civil Engineering, Institut Teknologi Adhi Tama Surabaya, Surabaya 60117, \\ Indonesia \\ jakapropika@gmail.com
}

\begin{abstract}
A bridge is a construction that connect two parts of the road cuts off by both natural and artificial obstacles. Meanwhile, a box culvert is a rectangular precast concrete structure that has a basic function as underground construction in the form of culverts, drains, and other supporting constructions. Those function of the box culvert is now developing as the main structure in the construction of bridges and highways. Thus, a research and evaluation should be done. The performance of the existing box culvert structures is in accordance with SNI 1725: 2016 regulations. The research methodology is done by manual calculation to get the load and reinforcement needs, while for static analysis by modelling the structure in SAP 2000 V.14.2.5 program. The material used is the existing material for top-bottom box culvert type $(4000 \times 4000 \times 1500) \mathrm{fc} '=30 \mathrm{MPa}$ and fy $=400 \mathrm{MPa}$. The results shows the reinforcement does not meet the minimum requirements of strong box structure reinforcement against bridge construction loads. The reinforcement ratio in plate slab area are almost close to the maximum ratio of reinforcement requirements. Whereas in the box culvert wall area, there is an overreinforcement so the dimensions must be increased.
\end{abstract}

\section{Introduction}

Along with the current development of construction technology, box culverts that previously functioned as supporting structures, are now developing as the main structure in the construction of bridges and highways. Changes and developments in this function naturally cause differences both in terms of loading and the need for reinforcement for the box culvert used. This is the basis of the need for research and evaluation of the performance of the box structure. The evaluation of existing culvert manufacturers with standard loads for bridges and highways in accordance with SNI 1725: 2016 regulations. The general objective of this research is to obtain certainty about the safety and strength of the box structure. That is capable of being used as a floor plate replacement element and girder beam on the bridge.

\section{Loading Concept for Bridges}

The planning of loading for bridges is generally regulated in SNI 1725 - 2016 and SNI 2833 - 2013, while the loading for planning box culvert with bridge load is outlined as follows:

\subsection{Permanent Load}

Permanent load on the bridge includes the weight of the building structure itself. It contains the upper structure to the lower structure coupled with non-structural dead loads such as asphalt and bridge accessories loads. 


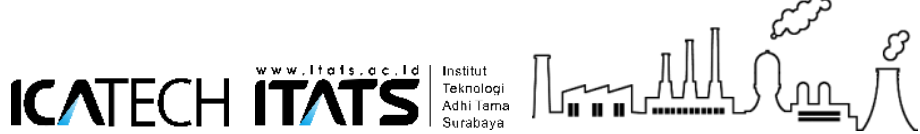

The $1^{\text {st }}$ International Conference on Advanced Engineering and Technology - 2018

Each component of dead loads must be considered an integral part of the action when applying the normal load factors and reduced load factors. The load factor for dead load and additional load used in planning are as follows.

Table 1. Load Factor for Dead Load contains Self Load and Additional Dead Load

\begin{tabular}{|c|c|c|c|c|}
\hline \multirow{3}{*}{ Load Type } & \multicolumn{4}{|c|}{ Load factor $\left(\gamma_{\mathrm{MS}}\right)$} \\
\hline & \multicolumn{2}{|c|}{ Serviceability limit state $\left(\gamma_{\text {MS }}^{\mathrm{S}}\right)$} & \multicolumn{2}{|c|}{ Ultimate limit state $\left(\gamma_{\mathrm{MS}}^{\mathrm{U}}\right)$} \\
\hline & Material & & Normal & Reduced \\
\hline \multirow{10}{*}{ Constant } & Steel & 1,00 & 1,10 & 0,90 \\
\hline & Aluminium & 1,00 & 1,10 & 0,90 \\
\hline & Precast concrete & 1,00 & 1,20 & 0,85 \\
\hline & Insitu concrete & 1,00 & 1,30 & 0,75 \\
\hline & Wooden & 1,00 & 1,40 & 0,70 \\
\hline & \multicolumn{4}{|c|}{ Load factor $\left(\gamma_{\mathrm{MA}}\right)$} \\
\hline & \multicolumn{2}{|c|}{ Serviceability limit state $\left(\gamma_{\mathrm{MA}}^{\mathrm{S}}\right)$} & \multicolumn{2}{|c|}{ Ultimate limit state $\left(\gamma_{\mathrm{MA}}^{\mathrm{U}}\right)$} \\
\hline & Condition & & Normal & Reduced \\
\hline & General & $1,00^{(1)}$ & 2,00 & 0,70 \\
\hline & Specific & 1,00 & 1,40 & 0,80 \\
\hline
\end{tabular}

Note $^{(1)}$ : Serviceability load factor 1,3 are used for utility weight

\subsection{Traffic Load}

Traffic loads for bridge planning consist of " $\mathrm{D}$ " lane loads and "T" truck loads [1]. In determining the amount of traffic load must be multiplied by a factor of dynamic load of $40 \%$ for bridges with a span of less than 50 meters.

2.2.1. Lane Load " $D$ ". Lane load "D" consists of the evenly distributed load (BTR) and the line load (BGT). The intensity of BTR is regulated in an article 8.3.1 which has a quantity of q $=9.0 \mathrm{kPa}$ for bridges with a maximum span of 30 meters, and a centered load of $\mathrm{P}=49 \mathrm{kN} / \mathrm{m}$. the loading model for the "D" lane load looks like in Figure 1.

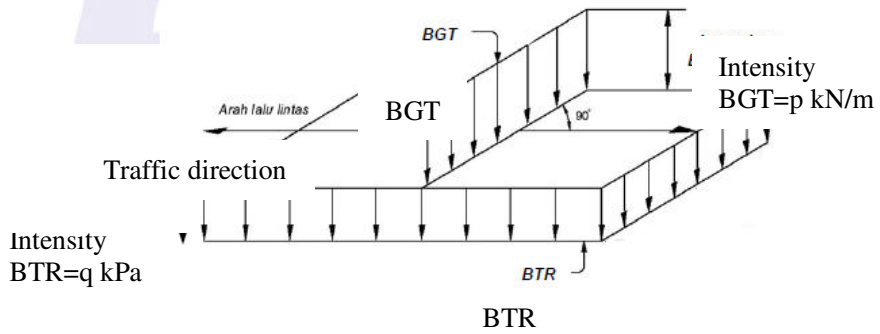

Figure 1. "D” Lane Load.

2.2.2. Truck Load " $T$ " (TT). In addition to the "D" load, there is another traffic load that needs to be taken into account, the load is a truck load "T". The "T" load cannot be used together with the "D" load. Truck load will be very dominant for short span bridges, besides that truck load must also be used for calculation of floor slab strength because the load " $\mathrm{T}$ " will greatly affect the need of steel ratio and thickness ratios floor plate. The traffic loads factor looks like the table below. 


\section{ICATECH ITATS}

The $1^{\text {st }}$ International Conference on Advanced Engineering and Technology - 2018

Table 2. Traffic Load Factor

\begin{tabular}{cccccc}
\hline \multirow{2}{*}{ Load Type } & Bridge Type & \multicolumn{2}{c}{ Load factor $\left(\gamma_{\mathrm{TD}}\right)$} & \multicolumn{2}{c}{ Load factor $\left(\gamma_{\mathrm{TT}}\right)$} \\
\cline { 3 - 5 } & $\begin{array}{c}\text { Serviceability limit } \\
\text { state }\left(\gamma_{\mathrm{TD}}^{\mathrm{s}}\right)\end{array}$ & $\begin{array}{c}\text { Ultimate limit } \\
\text { state }\left(\gamma_{\mathrm{TD}}^{\mathrm{U}}\right)\end{array}$ & $\begin{array}{c}\text { Serviceability limit } \\
\text { state }\left(\gamma_{\mathrm{TT}}^{\mathrm{s}}\right)\end{array}$ & $\begin{array}{c}\text { Ultimate limit } \\
\text { state }\left(\gamma_{\mathrm{TT}}^{\mathrm{U}}\right)\end{array}$ \\
\cline { 2 - 5 } Transient & 1,00 & 1,80 & 1,00 & 1,80 \\
\cline { 2 - 5 } & Steel Box Girder & 1,00 & 2,00 & 1,00 & 2,00 \\
\hline
\end{tabular}

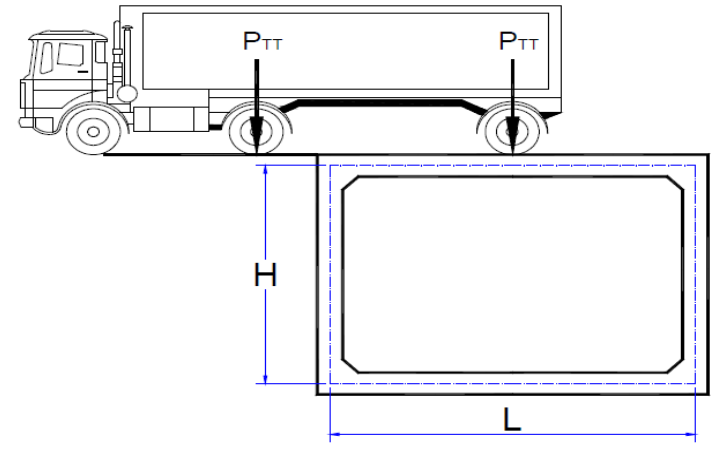

Figure 2a. Position of Truck Axle Load.

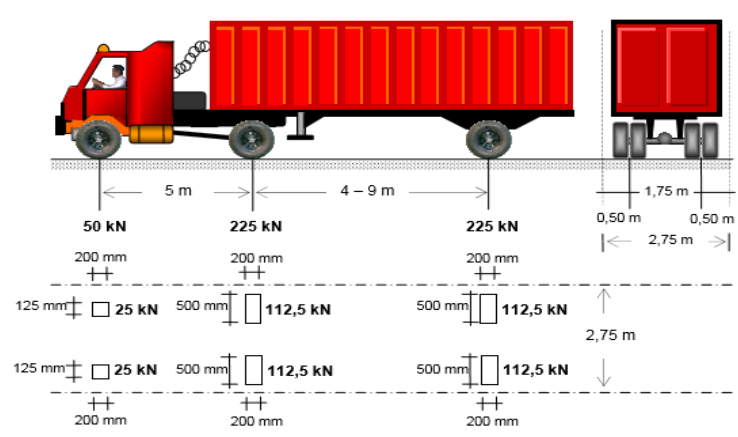

Figure 2b. Truck Axle Load $500 \mathrm{kN}$.

\subsection{Vehicle Brake Load (TB)}

In the bridge planning, the brake load must be taken from the largest values of: a. $25 \%$ of the designed weight of the truck axle or, b. 5\% of the weight of the planned truck and evenly distributed lane load (BTR). Brake loads must be placed horizontally on all traffic lanes.

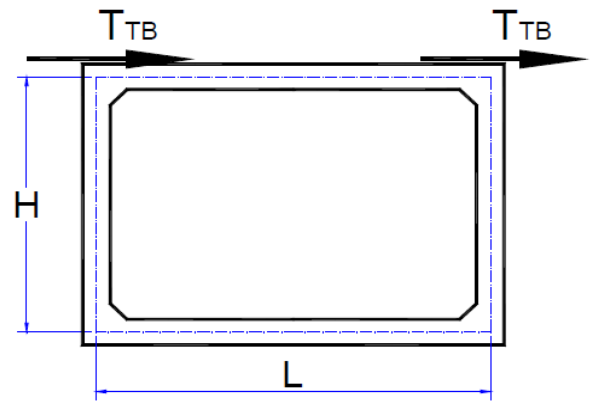

Figure 3. Brake Load Placement on Box Culvert.

\subsection{Soil Pressure Load (TA)}

The nominal soil pressure coefficient must be calculated based on soil properties. Physical properties of soil must be obtained based on the results of measurements and soil testing in the field or laboratory. Lateral soil pressure in the state of service limits is calculated based on the nominal values of $\gamma_{s}, c$ and Øf. Another factor in determining the amount of force due to lateral soil pressure on the box culvert is into the box and external load above the ground surface. 


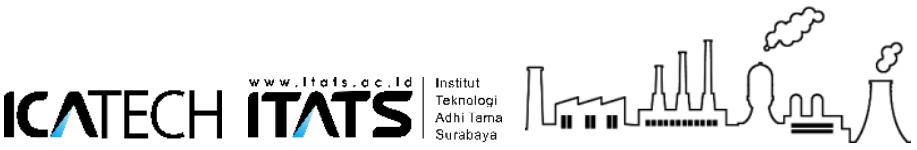

The $1^{\text {st }}$ International Conference on Advanced Engineering and Technology - 2018

Table 3. Soil pressure load factors.

\begin{tabular}{|c|c|c|c|c|}
\hline \multirow{3}{*}{ Load Type } & \multicolumn{4}{|c|}{ Load factor $\left(\gamma_{\mathrm{TA}}\right)$} \\
\hline & \multicolumn{2}{|c|}{ Serviceability limit state $\left(\gamma_{\mathrm{TA}}^{\mathrm{S}}\right)$} & \multicolumn{2}{|c|}{ Ultimate limit state $\left(\gamma_{\mathrm{TA}}^{\mathrm{U}}\right)$} \\
\hline & Soil Pressure & & Normal & Reduced \\
\hline \multirow{5}{*}{ Constant } & Vertical & 1,00 & 1,25 & 0,80 \\
\hline & Lateral & & & \\
\hline & - Active & 1,00 & 1,25 & 0,80 \\
\hline & - Passive & 1,00 & 1,40 & 0,7 \\
\hline & - At rest & 1,00 & (1) & (1) \\
\hline
\end{tabular}

Note $^{(1)}$ : Lateral soil pressure at rest usually not included in ultimate limit condition

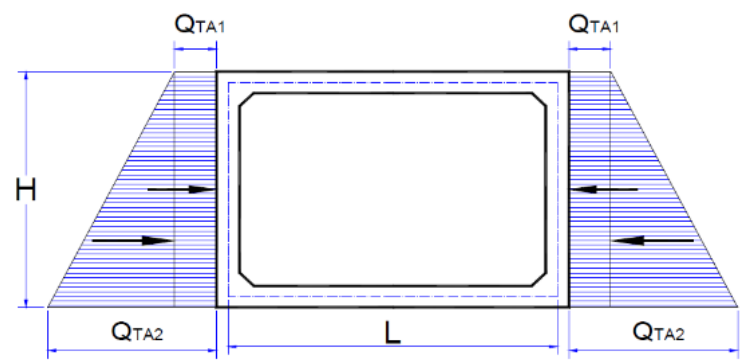

Figure 4. Lateral Soil Pressure.

\subsection{Static Equivalent Earthquake Load}

The earthquake load is taken as a horizontal lateral force which is determined based on the multiplication between the elastic response coefficient $\left(\mathrm{C}_{\mathrm{sm}}\right)$ and the equivalent structural weight $\left(\mathrm{W}_{\mathrm{t}}\right)$ which is then divided by the response modification factor $\left(\mathrm{R}_{\mathrm{d}}\right)$ [2].

$$
E_{Q}=\frac{C_{s m}}{R_{d}} x W_{t}
$$

\subsection{Dynamic Soil Pressure Due to Earthquake Load}

The lateral earthquake load due to dynamic soil pressure is calculated using the dynamic soil pressure coefficient $\left(\Delta K_{a G}\right)$ as follows [3][4]:

Thus, dynamic soil pressure is formulated:

$$
\begin{aligned}
& \theta=\tan ^{-1}\left(K_{h}\right) \\
& K_{a G}=\frac{\cos ^{2}\left(\phi^{\prime}-\theta\right)}{\cos ^{2} \theta \cdot\left\{1+\sqrt{\frac{\left(\sin \phi^{\prime} \cdot \sin \left(\phi^{\prime}-\theta\right)\right.}{\cos \theta}}\right\}} \\
& \Delta K_{a G}=K_{a G}-K_{a}
\end{aligned}
$$

$$
Q_{E Q}=H \cdot W_{s} \cdot \Delta K_{a G}
$$

With $\mathrm{H}$ is box culvert height, $\mathrm{W}_{\mathrm{s}}$ is soil unit weight. 


\section{KATECH ITATS}

The $1^{\text {st }}$ International Conference on Advanced Engineering and Technology - 2018

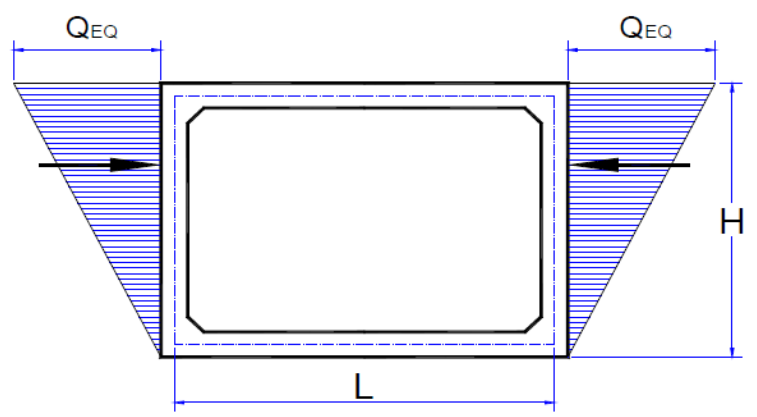

Figure 5. Load Placement due to Earthquake Dynamic Earthquake Pressure.

\subsection{Soil Uplift Pressure}

Uplift pressure is the lifting force of the building's base surface due to differences in building elevation. The amount of uplift pressure can be calculated by the following formula [5][6]:

$$
Q_{\text {uplift }}=\gamma \cdot Z . A
$$

Where: $\gamma$ is water unit weight, $\mathrm{Z}$ is a delta elevation of groundwater table with slab, $\mathrm{A}$ is area which influenced by uplift pressure.

\section{Methodology}

The implementation phase of the research was carried out by controlling the ratio of reinforcement of existing culvert boxes. It then carried out the loading with the bridge load and obtained the reinforcement ratio plan.

\subsection{Data Planning Specification}

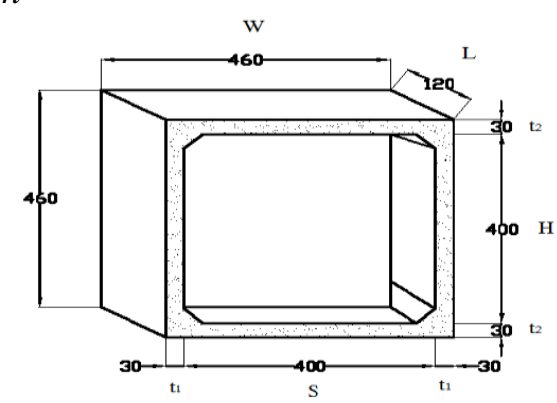

Figure 6. Box Culvert Dimension.

- Main structure

- Dimension

- Bridge height

- Bridge width

- River width

- River depth

- Concrete compressive strength

- Steel bar U-40 tensile strength

- Steel bar U-24 tensile strength
: Box Culvert

: 4,00 x 4,00 x $1,20 \mathrm{~m}$

: $4,80 \mathrm{~m}$

: $9,164 \mathrm{~m}$

: $18,40 \mathrm{~m}$

: Groundwater table 3,00 m

: $30 \mathrm{MPa}$

: $400 \mathrm{MPa}$

: $240 \mathrm{MPa}$ 


\section{KATECH ITATS}

The $1^{\text {st }}$ International Conference on Advanced Engineering and Technology - 2018

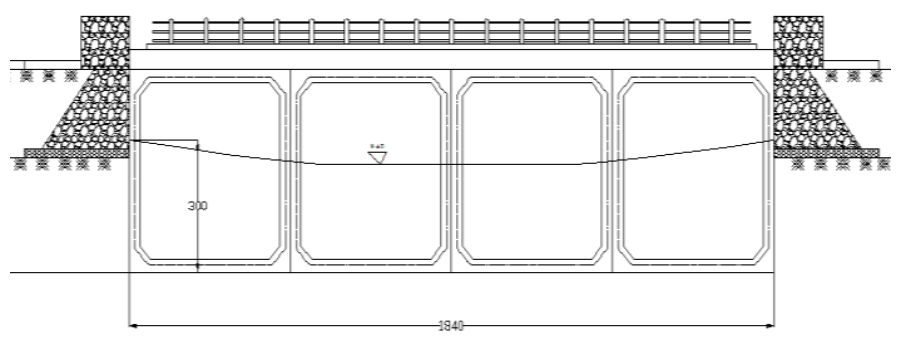

Figure 7. Cross section of existing bridge plan.

\subsection{Load input in Box Culvert}

The loading analysis are based on SNI 1725-2016.

- $\quad$ Self Weight QMS

- Additional Dead Weight QMA

- Lane Load "D" PTD

- Truck Load "T" PTT

- Pedestrian Load QTP

- Wind Load TEW

- Earthquake Load TEQ

- Vehicle Brake Load TTB

- Soil Pressure Load on Box Culvert Wall Plate QTA1

- Soil Pressure Load on Box Culvert Wall Floor Plate QTA2 = 89,44 kN/m

- Lateral Earthquake Load QEQ

- Temperature Difference on Floor Plate $\Delta T$

- Uplift Load due to Water

- Uplift Load due to "D" details.

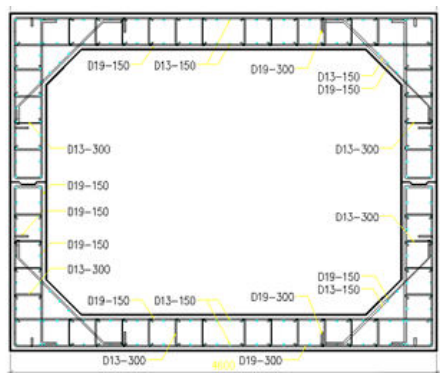

Figure 8. Box culvert steel bar

$$
\begin{gathered}
=9,711 \mathrm{kN} / \mathrm{m} \\
\quad=1,60 \mathrm{kN} / \mathrm{m} \\
=68,6 \mathrm{kN} \\
\quad=315 \mathrm{kN} \\
=2,5 \mathrm{kN} / \mathrm{m} \\
=5,40225 \mathrm{kN} / \mathrm{m} \\
=12,915 \mathrm{kN} \\
=2,99 \mathrm{kN} \\
=10,32 \mathrm{kN} / \mathrm{m} \\
=89,44 \mathrm{kN} / \mathrm{m} \\
\quad=-18,538 \mathrm{kN} / \mathrm{m} \\
=12,5^{\circ} \mathrm{C} \\
=55,2 \mathrm{kN} / \mathrm{m} \\
=16,56 \mathrm{ton}
\end{gathered}
$$

\section{Results and Discussion}

Analysis and comparison were carried out using the data in the existing box culvert. Where the results of the analysis focused on the flexural behaviour of the floor plate structure elements and the box culvert wall. As for the results of the analysis comparison according to Table 4. 


\section{ICATECH ITATS =}

The $1^{\text {st }}$ International Conference on Advanced Engineering and Technology - 2018

Table 4. Traffic Load Factor.

\begin{tabular}{llcccc}
\hline $\begin{array}{l}\text { Reinforcement } \\
\text { bar area }\end{array}$ & $\begin{array}{l}\text { Reinforcement } \\
\text { bar condition }\end{array}$ & $\begin{array}{c}\text { Concrete } \\
\text { compresive } \\
\text { strength (MPa) }\end{array}$ & $\begin{array}{c}\text { Reinforcement bar } \\
\text { tensile strength } \\
\text { (MPa) }\end{array}$ & $\begin{array}{c}\text { Reinforcement } \\
\text { bar ratio }\end{array}$ & Annotation \\
\hline $\begin{array}{l}\text { Upper } \\
\text { reinforcement } \\
\text { support area }\end{array}$ & Existing & 30 & 400 & 0.00236 & Not OK \\
$\begin{array}{l}\text { Upper } \\
\text { reinforcement } \\
\text { mid-span area }\end{array}$ & Existing & 30 & 400 & 0.0186 & \\
$\begin{array}{l}\text { Upper } \\
\text { reinforcement }\end{array}$ & Existing & 30 & 400 & 0.004723 & Not OK \\
$\begin{array}{l}\text { wall box } \\
\begin{array}{l}\text { Lower } \\
\text { reinforcement } \\
\text { support area }\end{array}\end{array}$ & Planning & 30 & 400 & 0.0186 & \\
$\begin{array}{l}\text { Lower } \\
\text { reinforcement } \\
\text { mid-span area }\end{array}$ & Existing & 30 & 400 & 0.004723 & Not OK \\
$\begin{array}{l}\text { Lower } \\
\text { reinforcement }\end{array}$ & Existing & 30 & 400 & 0.035 & Not OK \\
wall box & Planning & 30 & 400 & 0.00236 & Not OK \\
\hline
\end{tabular}

\section{Conclusions}

From the results of the analysis carried out on the existing box culvert as the main structure of the bridge on the arterial highway, it can be concluded as follows: The need for reinforcement of existing box culverts that are usually used as supporting structures (channels and culverts), does not meet the minimum requirements of strong box structure reinforcement against bridge construction loads in accordance with SNI 1725-2016 regulations. Based on the ratio of reinforcement requirements, the existing box culvert is at risk of experiencing flexural failure that occurs in almost all parts of the box culvert. It occurs both on the upper floor plate, the box wall and also the lower floor plate. There is an indication of fault analysis on the existing box culvert. It could be assumed that the top of the floor plate, either the top or bottom area is the foundation of the joint placement system. Which should be the support of the pinch system, this could be seen from the existing reinforcement ratio which shows that the field area has a ratio twice as large as the pedestal. The results of the reinforcement needs analysis for box structures with bridge loads show that the cross-section thickness of the box structure culverts on the slab area, whether the top or bottom parts need additional thickness, this could be seen from the reinforcement ratio that is almost close to the maximum ratio of reinforcement requirements in a section reinforced concrete. Whereas in the box culvert wall area, there is an over reinforcement so that the cross-section must be enlarged. Another alternative solution for box culverts that are able to withstand bridge loads other than by increasing the number of reinforcement and cross-section thickness by increasing the quality of the concrete box culvert and adding prestressed by using post tension system. 


\section{ICATECH ITATS E}

The $1^{\text {st }}$ International Conference on Advanced Engineering and Technology - 2018

\section{References}

[1] National Standardization Institute, "Loading for bridges (SNI 1725 - 2016)," 2016.

[2] National Standardization Institute, "Bridge planning due to earthquake (SNI 2833 - 2013)," 2013.

[3] N. Mononobe and H. Matsuo, "The determination of earth pressure during earthquakes," in Proc. Int. Conf. of the World Engineering, 1929.

[4] S. Okabe, "General theory of earth pressure," J. Japanese Soc. Civ. Eng., vol. 12, no. 1, 1926.

[5] U.S. Department of Transportation Federal Highway Administration, "Ground anchors and anchored systems," Washington D.C., 1999.

[6] American Concrete Institute, "Design considerations for environmental engineering concrete structures (ACI 350.4R-04)," Farmington Hills, 2004. 